\title{
Universiteit
}

Leiden

The Netherlands

\section{A New Offering Table for Shepenwepet}

Hays, H.M.

\section{Citation}

Hays, H. M. (2003). A New Offering Table for Shepenwepet. Journal Of The American Research Center In Egypt, 40, 47-60. Retrieved from https://hdl.handle.net/1887/16164

Version:

Not Applicable (or Unknown)

License:

Leiden University Non-exclusive license

Downloaded from: $\quad$ https://hdl.handle.net/1887/16164

Note: To cite this publication please use the final published version (if applicable). 


\title{
A New Offering Table for Shepenwepet
}

\author{
HAROID M. HAYS
}

In its 2001-2002 field season, the Epigraphic Survey of the Oriental Institute recovered a new offering table for the God's Wife Shepenwepet II from among foundation fill in one of the sanctuaries within the small temple to Amun at Medinet Habu. ${ }^{1}$ Although the detailed circumstances of its recovery and a facsimile of its texts will be presented in a future Epigraphic Survey publication, photographs of its inscriptions and a hand copy are offered here, along with both a preliminary description of it and a discussion of its context, especially in respect to its ownership, its style, and the inscription upon its platter.

It is shaped of dark granite with the rough grain characteristic to that stone, making the reading of its signs difficult from a distance and preventing the kind of subtlety and finesse of carving that might have been gotten from a finer stone, such as limestone. Nevertheless, its figures and signs were carved with skill and care, making readings clear where the table has not suffered damage.

The principal points of damage are on the platter's front left hand corner (to adopt the point of view of a priestly officiant who would have performed rites over $\mathrm{it}^{2}$ ), where a large piece was anciently broken off, and within the cartouches of the father of Shepenwepet, presumably giving the name of Piye ("Piankhy") ${ }^{3}$ prior to being attacked. ${ }^{4}$ As for the missing chunk, this could have been broken off at any time after the table's being finished and before being deposited in the small temple, where it was to serve as ad hoc foundation for the Ptolemaic granite naos that would be installed above it. ${ }^{5}$

Prior to the front left hand corner's being damaged, the platter would have measured $104 \mathrm{~cm}$ wide by $64 \mathrm{~cm}$ deep, with the cake jutting out from its $h t p$-sign shape adding another $23 \mathrm{~cm}$ to the depth. The platter itself is about $19 \mathrm{~cm}$ high, and the total height of the table from very bottom to very top of the platter is about $66.5 \mathrm{~cm}^{6}$

A draft of this article was presented at Johns Hopkins University at the 2002 Annual Meeting of the American Research Center in Egypt. It has greatly benefited from the suggestions of Robert K. Ritner and the JARCE referee, though the responsibility for its contents is mine.

${ }^{1}$ In Room P, according to the designation of Uvo Hölscher, The Excavation of Medinet Habu-Volume II: The Temples of the Eighteenth Dynasty, OIP 41 (Chicago, 1939), 15.

2 To follow the practice of Jacques J. Clère, "La table d'offrandes de l'échanson royal Sa-Rénénoutet surnommé Tchaouy," BIFAO 81 Supplement (1981), 213-34, 216 with n. 1.

${ }^{3}$ As her filiation is attested on numerous monuments; see Jean Leclant, Recherches sur les monuments thébains de la XXVe Dynastie dite ethiopienne, BdE 36. Text (Cairo, 1965), 359 with n. 2.

${ }^{4}$ Under Psammetichus II; see Jean Yoyotte, "Le martelage des noms royaux éthiopiens par Psammétique II," $R d E 8$ (195I), 215-39.

${ }^{5}$ On the naos, see Hölscher, Excavation of Medinet Habu $I I, 15$ with fig. 15 and further reference at his n. 12; his dating "fourth century B.C. Or later" is based on the paleography of the Demotic signs used to label the wall blocks of the west wall of Room $\mathrm{P}$ to aid in the wall's reassembly, the wall having been partially dismantled in order to permit the naos to be introduced; Hölscher is reporting the assessment of William F. Edgerton.

${ }^{6}$ The measurements are courlesy of $\mathrm{J}$. Brett McClain. 


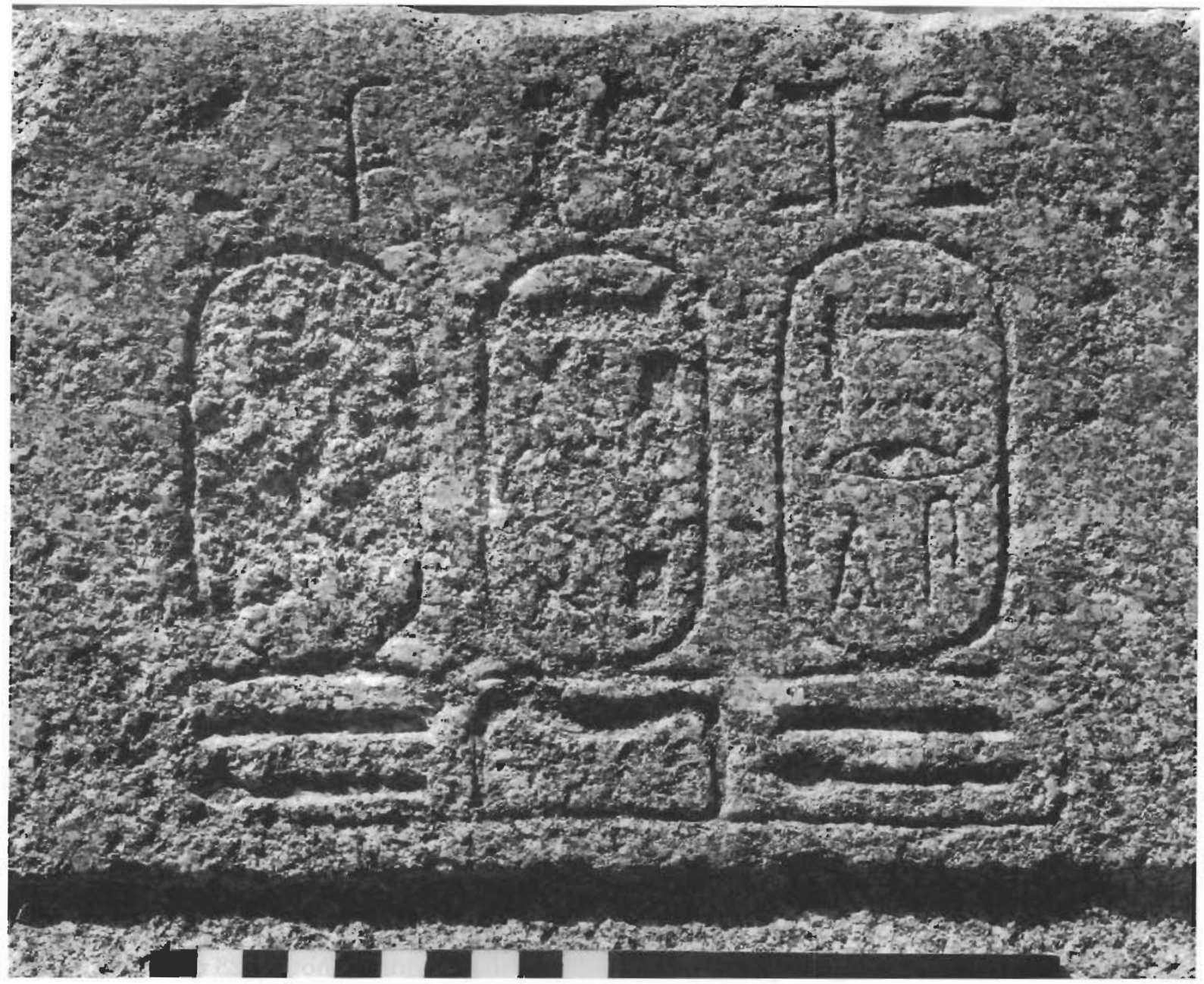

Fig. 1. Cartouches on the back side (Photograph: Yarko Kobylecky)

Cartouches designating the beneficiary as Shepenwepet, (adoptive ${ }^{7}$ ) daughter of Amenirdis and daughter of a king, appear on the platter as well as on the back side of the table (Fig. 1), facing away from any officiant who would have performed service over it and toward whatever was set up in front of it, presumably a false door or some other item bearing an image of her.

An image of Shepenwepet and a number of other objects appropriate to the funerary provisioning of the God's Wives were recovered from Medinet Habu in Hölscher's and earlier excavations, sometimes, like the newly recovered offering table, in proximity to the small temple of Amun, ${ }^{8}$ but also nearer their chapels, though nothing was found in the plundered crypts beneath them. Especially

${ }^{7}$ She was adopted in the reign of Piye, in the view of Leclant, Recherches sur les monuments, 362. With Amenirdis I as the sister or half-sister of Piye (according to Kenneth Kitchen, The Third Intermediate Period in Egypt (1100-650 B.C.), 2nd ed. (Warminster, 1986), 359 (\$321)), Amenirdis would be Shepenwepet's biological aunt.

${ }^{8}$ As with the image of Shepenwepet just now mentioned, found south of the sacred lake; presumably through reason of its proximity to the Small Temple and its distance from her own chapel, Uvo Hölscher The Excauation of Medinet Habu-Volume V: Post-Ramessid Remains, OIP 66 (Chicago, 1954), 28, was led to suppose that this image originally stood in the Small Temple rather than in her chapel. But the newly recovered offering table of hers was also found remotely from her chapel and even within the Small Temple. 
because numerous ushebtis were among the objects, it is possible that the God's Wives were buried in these crypts, ${ }^{9}$ in parallel to a roughly contemporaneous practice of royal burial within the temple precinct at Tanis, as with Psusennes, Osorkon II, and others. ${ }^{10}$ In accord with their location within a temple precinct, there are indications that the God's Wives' chapels themselves were structures devoted to mortuary cult, beginning with the designation of Amenirdis's chapel as a Ka-House. ${ }^{11}$ It is within such a ritual context that this and other offering tables may be situated, as presumably the table would have been placed somewhere within the space of Shepenwepet's chapel area. Exactly where within is something unknown, since both this and another table of hers, to be discussed presently, were found outside of their original physical contexts.

The carvings on its platter both structure and are structured by its ritual context. As may be seen in the platter photo (Fig. 2) and hand copy (Fig. 3), the most prominent manifestation of the ritual association is the libation trough leading out from its center and making a kind of spout out of the cake jutting from its $h t p$-sign shape, a very traditional shape, having its origins in offering tables with $h t p$-designs as far back as the Old Kingdom. ${ }^{12}$ The table accordingly was meant to receive poured liquids. That it was meant to receive offerings of both food and liquids is suggested by the depictions of fowl, three kinds of bread, and jars cut into the platter, just above a representation of a $h t p$-sign within the platter. The platter is itself of $h t p$-shape, $h t p$ of course being the term for "offering." 13

The inscriptions in the band around the perimeter of the platter illustrate the table's cultic position: first, beginning at the right center of the far horizontal, a vocative to the beneficiary, Shepenwepet, daughter of a king, presumably Piye; next, Pyramid Texts utterance 44 begins on the right vertical and near right horizontal, where the ancient text gains an accretion. The inscription continues at the left center of the far horizontal with a second vocative to Shepenwepet, daughter of Amenirdis, the utterance concluding on the left vertical and the near left horizontal, with yet another

\footnotetext{
${ }^{9}$ On the associated items and for this view, see Hölscher, Excavation of Medinet Habu V, 26-28.

${ }^{10}$ See Rainer Stadelmann, "Das Grab im Tempelhof: Der Typus des Königsgrabes in der Spätzeit," MDAIK 27 (1971), 11123, esp. 114-18.

11 As at Nelson designation MH C 100; see OI Negative 1596: ir(.t) $n=s$ hw.t-k 3 m inr h $h$ nfr "making for her (sc. Amenirdis) a Ka-House out of fine, white stone." The Ka-House's relation to mortuary cult is owed to the ancient, intimate association of the Ka with the cult statue; see Liselotte Greven, Der Ka in Theologie und Königskult der Ägypter des Alten Reiches, ÄF 17 (Gluckstadt, 1952), 32-33; Hermann Junker Gîza III (Vienna, 1938), 121 ; and Andrey O. Bolshakov, Man and His Double in Egyptian Ideology of the Old Kingdom, ÄAT 37 (Wiesbaden, 1997), 147-48 and 209. Mortuary chapels within temple complexes seem to have been called "Ka-Houses" since the Old Kingdom; see Hans Goedicke, Königliche Dokumente aus dem Alten Reich, ÄA 14 (Wiesbaden, 1967), fig. 4 (= Urk I 214, 11), where-below a scene depicting the king followed by his mother Iput in the act of

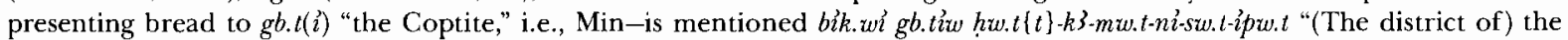
Two Falcons, Coptos, the Ka-House of the King's Mother lput." See further citations at Ursula Schweitzer, Das Wesen des Ka in Diesseits und Jenseits der alten Ägypter, ÄF 19 (Gluckstadt, 1956), 85 with $\mathrm{n} .45$, but note also references to foundation estates referred to as Ka-Houses at $86 \mathrm{n} .48$, a usage that suggests that the term had a broader significance.

12 One of a plethora of examples is CG 1328, for which see Ludwig Borchardı 1937 Denkmäler des Alten Reiches (ausser den Statuen), Part 1, Catalogue Générale vol. 97 (Berlin, 1937), pl. 4.

${ }^{13}$ As understood by Regina Hölzl, Ägyptische Opfertafeln und Kultbecken, HÄB 45 (Hildesheim, 2002), 133-34, the word signifies the deceased's being provisioned with offerings; compare the interpretation of Alan $\mathrm{H}$. Gardiner in Nina de Garis Davies and Alan H. Gardiner, The Tomb of Amenemhet (No. 82), TTS 1 (London, 1915), 80, where the word is held to literally mean "'satisfaction,' 'contentment,' and refers to the feelings aroused by the presentation of offerings." Too limited is the meaning attributed to the word by Maha M. F. Mostafa, Untersuchungen zu Opfertafeln im Alten Reich, HÄB 17 (Hildesheim, 1982), 89, who believes hip to have originally referred to the state resulting from the consumption of a meal, this view based on a single Dynasty 6 text. Rather, its specific meaning as "offering" may be understood as deriving from a more general meaning of "to be satisfied," since in the Old Kingdom htp was employed in a variety of contexts well beyond the scope of food and drink, e.g., at Urk I 225, 8-9, where a noble states that he caused his statue to be made by a sculptor htp hr isw ir.t.n(=i) $n=f$ "precisely with him being satisfied with the remuneration that I made to him," and, e.g., Elmar Edel, "Inschriften des Alten Reichs III. Die Stele des Mhw-3htj (Reisner G 2375)," MIO 1 (1953), 327-36, 328 pl. 2 B6 (with similar statements appearing at Urk I 199, 1; 200, 16; and 222, 12): [i $i w] w p . n(=\hat{i}) s n$. wi $r h t p=s n(\hat{\imath})$ "I judged two equals in order that they be satisfied." Also drawn from or resting in this same broad field of meaning may be understood $h t p$ in its sense of "to set," as at Pyr. 1835b: $h t p=f h n^{c}=f$ $m$ imn "with him (the beneficiary) setting with him (Re) in the West." See also below, n. 77.
} 


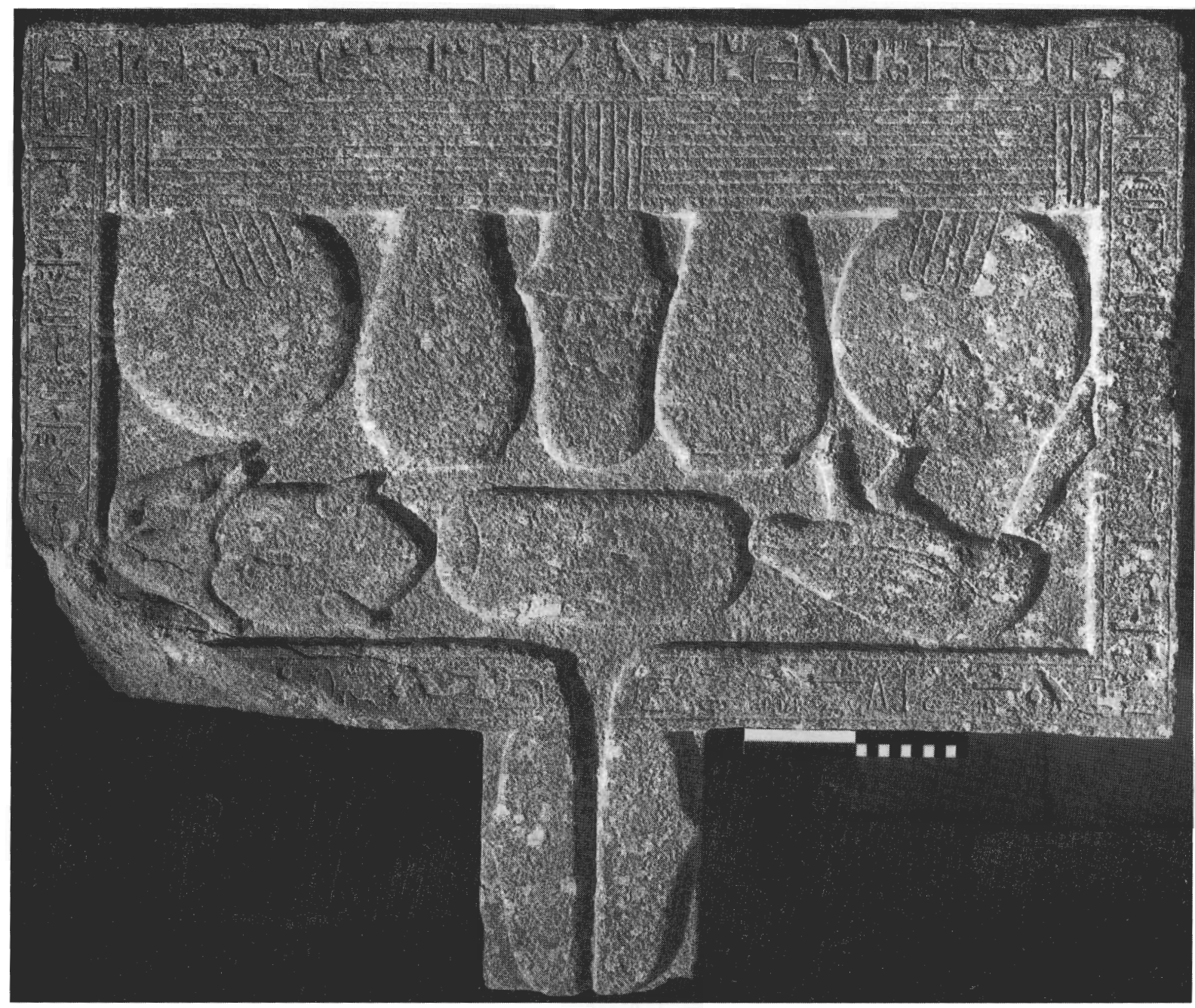

Fig. 2. Platter (Photograph: Yarko Kobylecky)

accretion. The vocatives situate Shepenwepet as cultic recipient; the Pyramid Texts utterance, as will be discussed, is from the offering ritual within mortuary service and, as elsewhere, is tailored by its pronouns ${ }^{14}$ to designate her as recipient of its grace; and, not insignificantly, the first addition to the original text includes the term htp-di-ny-sw.t, traditionally referring to mortuary service archetypally performed for the deceased by the king ${ }^{15}$ as quintessential cultic officiant.

Taking the sum of its parts together, this table is an excellent example of what Leclant called the "Ethiopian type." ${ }^{16}$ In fact, a number of contemporary tables are nearly identical to it, right down to the texts upon them. For the present discussion, the most important of these is the other table of Shepenwepet's (Fig. $4^{17}$ ), excavated long ago by Daressy from within the greater Medinet Habu pre-

14 The suffix pronoun appearing consistently as the classic $=t$ rather than $=t$; see fig. 3 . The two are interchangeable in Shepenwepet's other table, e.g. with htp $n=t r^{\prime}$ 'imy p.t. . htp $n=t$ nb.ti; see fig. 4.

15 As noted by Jan Assmann, “Totenkult, Totenglauben," L̈̈ VI, 659-76, 663.

16 Paul Barguet, Zakaria Goneim, and Jean Leclant, "Les tables d'offrandes de la grande cour de la tomb de Montouemhât," ASAE 51 (1951), 491-507, 501, and Leclant, Recherches sur les monuments, 168 n. 1.

17 Previously published at Barguet et al., "Les tables d'offrandes," pl. 7; presented here as well for purposes of comparison. 


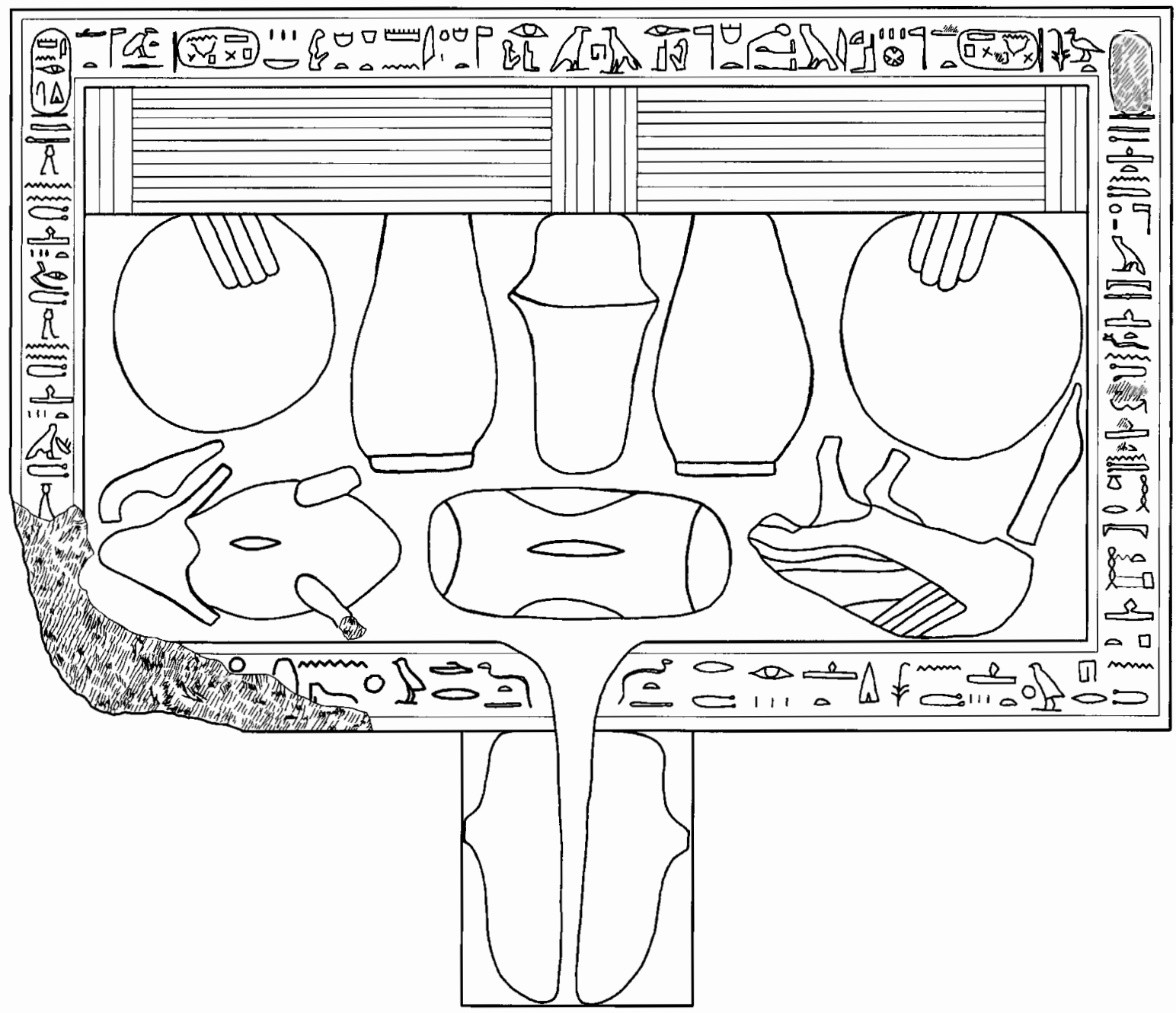

Fig. 3. Platter of the newly recovered table (Hand copy: Harold M. Hays)

cinct $^{18}$ but today situated within the court of Amenirdis's chapel, immediately adjacent to Shepenwepet's. Besides Shepenwepet's second table, her contemporary Montuemhat ${ }^{19}$ and Montuemhat's Nubian wife, Wedjarenes, ${ }^{20}$ have tables much like this new one. All four of them have a $h t p$-shaped platter, an arrangement of three kinds of bread, fowl, and two jars over an internal $h t p$-sign, these being surrounded by nearly the same inscription, including PT 44. However, the "Ethiopian type" of table is more characterized by the physical arrangement of inscriptions around the platter and the nature of the objects appearing on it than by textual similitude. Above all, PT 44 may be replaced by

${ }^{18}$ On this table, see G. Daressy, "Notes et remarques," RT 20 (1898), 72-86, 75; Hölscher, Excavation of Medinet Habu V, 28 with fig. 31; Barguet et al., "Les tables d'offrandes," 506-7 with pls. 7-8; and further references at Leclant, Recherches sur les monuments, 169 (D, 17).

${ }^{19}$ See Barguet et al., "Les tables d'offrandes," 491-93 with pl. I.

${ }^{20}$ See Barguet et al., "Les tables d'offrandes," 493-94 with pl. 2; Yoyotte, "Le martelage des noms royaux éthiopiens," 234; and Edna R. Russmann, "Mentuemhat's Kushite Wife (Further Remarks on the Decoration of the Tomb of Mentuemhat, 2)," JARCE 34 (1997), 21-39, 24 with n. 31. 


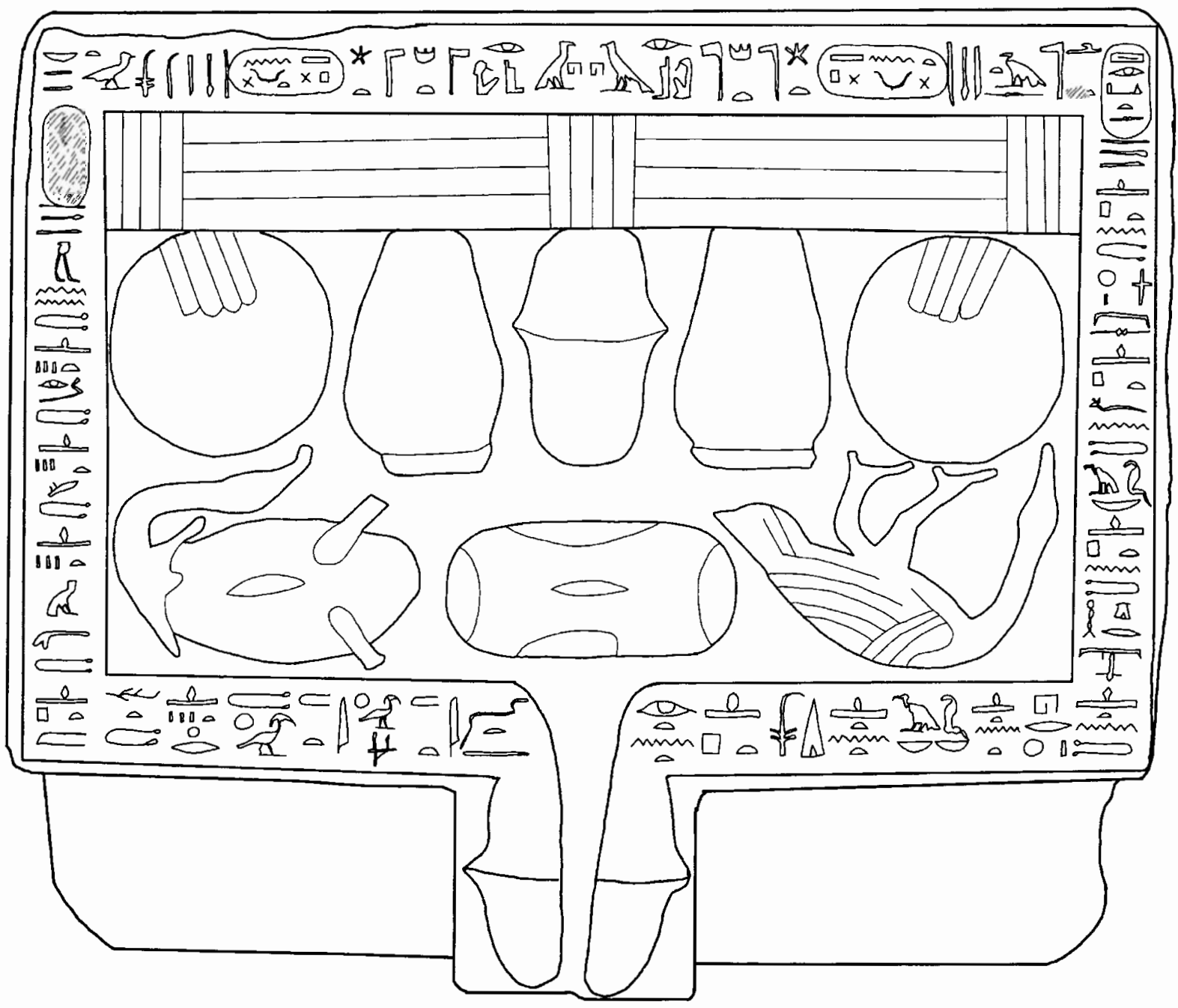

Fig. 4. Platter of the table excavated by Daressy (Hand copy: Harold M. Hays)

$h t p$-di-ny-sw.t formulae or other utterances (such as an extract from PT $424^{21}$ ), as with a table for Shepenwepet's immediate predecessor the God's Wife Amenirdis I, ${ }^{22}$ a second table of Montuemhat, ${ }^{23}$ a table of the official Gemaset, ${ }^{24}$ and a table of Basa from Dynasty $26 .{ }^{25}$ Tables reckoned to this type thus begin to appear in Dynasty 25, the "Ethiopian dynasty," and continue into Dynasty 26, certainly not an "Ethiopian dynasty."

21 Pyr, 772b-774b on a contemporary table from TT34; Barguet et al., "Les tables d'offrandes," pl. 4.

22 See Ahmed Bey Kamal, Tables d'offrandes, Catalogue Générale vols. 46-47 (Cairo, 1906), 85 and pl. 21.

23 See Barguet et al., "Les tables d'offrandes," 494-96 with pl. 3.

24 Berlin Staatliche Museen 7497; see Erhart Graefe, Untersuchungen zur Verwaltung und Geschichte der Institution der Gottesmahlin des Amun vom Beginn des Neuen Reiches bis zur Spätzeit, ÄA 37 (Wiesbaden, 1981), vol, 1, 198-99 and pl. 1 (P3).

${ }^{25}$ BM 967, brought to my attention by Will Schenck. For the table, see Jan Assmann, Das Grab des Basa (Nr. 389) in der thebanischen Nekropole, AV 6 (Mainz am Rhein, 1973), 16 with fig. 7, and see 22 for the date of Basa: reign of Psammetichus 1, following Montuemhat and Nesptah Il. 
But the new table of Shepenwepet is of interest not only for being a fine example of a type but also for being one of two tables dedicated to her. Her other table is closely akin to this one in form, depictions, and texts. At first it might seem puzzling that a single person should have two offering tables dedicated to her; perhaps one would expect that only one would be needed, especially within the restrictive confines of Shepenwepet's chapel at Medinet Habu. But just now mentioned were two tables of her contemporary Montuemhat, both of them excavated from his Grabpalast at Thebes (TT 34), ${ }^{26}$ and so the circumstance of two tables for one person in this period is not unknown. To attempt to explain why Shepenwepet might have had two, one might assume that each table was used in a different stage of the mortuary service. A simpler explanation might be that the newly recovered table had become damaged, its corner knocked off, and so the table excavated by Daressy was prepared as a replacement. ${ }^{27}$ But other scenarios could be envisaged, and it is difficult to choose among the possibilities that imagination can generate. Making a hypothesis is complicated all the more since both tables were found outside of their original contexts-the newly recovered table buried under the small temple's Ptolemaic naos as ad hoc foundational support, and the old from somewhere outside the temple's enclosure wall. ${ }^{28}$

However they were used, a closer comparison of them can draw out differences enough to suggest that they were crafted separately. First, they are of slightly different granites, the old table's granite being darker and smoother; the new table more coarse. The old table is of seemingly unfinished condition, with a kind of shelf on either side of the cake jutting out from the htp-shape; the new table, in contrast, seems fully finished from top to bottom, complete with a thin, molded band wrapped around the platter's pedestal; this is in addition to the pedestal's general symmetry of shape, compared to irregular bulges in the old table's pedestal. ${ }^{29}$ Also, the newly recovered table has its platter inscription banded on either side by incised lines; the old table lacks them; its platter inscription is banded only by changes in elevation. Last, even though their platter inscriptions have essentially the same content, there are noteworthy variations between them. Chief of these are the writings of the name of Shepenwepet's adoptive mother Amenirdis, with the old table showing a unique orthography. ${ }^{30}$ There are also variations in the titles given to Shepenwepet ${ }^{31}$ and there are some differences in clauses and phrases within PT $44 .{ }^{32}$ Figure 5 synoptically shows the best preserved of the published

${ }^{26}$ Barguet et al., "Les tables d'offrandes," 491, for provenance.

27 As suggested to me by Bill Petty.

${ }^{28}$ According to Daressy, "Notes et remarques," 75, it was found "à l'a extérieur du mur d'enceinte."

${ }^{29}$ The most pronounced of these irregularities is displayed in the photograph of Hölscher, Excavation of Medinet Habu V, 28 fig. 31. The unfinished state of the pedestal led Hölscher to suppose that the table was designed to be let into the floor.

${ }^{30}$ With Leclant, Recherches sur les monuments, 356 n. 3, noting the uniqueness.

31 On Sh 1: hm.t ntr dw3.l ntr šp-n-wp.t $m 3^{c}(. t)$-hrw "God's Wife, Adoratrice of the God Shepenwepet, True of Voice." On Sh2:

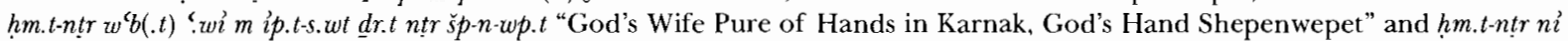

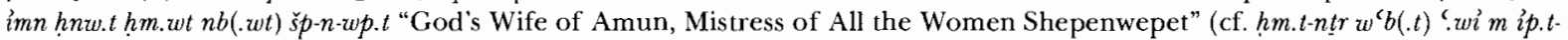
s.zt to the similar title $h m . t$-ntr w'b(.t) ' wi $n(\hat{\prime})$ imn, cited at C. E. Sander-Hansen, Das Gottesweib des Amun (Copenhagen, 1940), 12; and cf. hnw.t hm.wt $n b(. w t)$ to the title hrit wr.t hnr.t tpit, discussed extensively at Saphinaz-Amal Naguib, Le clergé féminin d'Amon thébain à la $21^{\mathrm{e}}$ dynastie, OLA 38 (Leuven, 1990), 188-207). The title given to Amenirdis is the same on Sh1 and Sh2: dr.t ntr imn-ir-di-s m3'(.t)-hrw "God's Hand Amenirdis, True of Voice."

${ }^{32}$ Most prominently, like Mon. and Wedj., Sh2 omits htp $n=t n b$. ti of Pyr. $34 \mathrm{~b}$, although it is attested in the other exemplars. But Sh2, unlike any of the other exemplars, adds the participial phrase in $n=t$ after $h t p . w m 3(3)=t$ in $34 \mathrm{c}$ and probably after $s \underline{d} m=t$ in the same line, though the damage to the left front comer leaves only in in the second case. Singular to the new table is the odd writing of $h t p$ at Pyr. $34 \mathrm{~b}(h t p n=t h r w$ ) with full phonetic complements at the very beginning of the word, making redundant the otherwise typical phonetic complements at the end of it. As observed to me by Randy Shonkwiler, the initial phonetic complements were a secondary addition intended to replace an older and mistaken $n=t$, traces of which are still clearly visible. Last, one notices that the offering tables omit the ritual instruction at the end of PT 44. e.g., in W. p3.t ws d. $\iota$, but make short insertions in the middle and, with Sh1 and Sh2, at the end. 

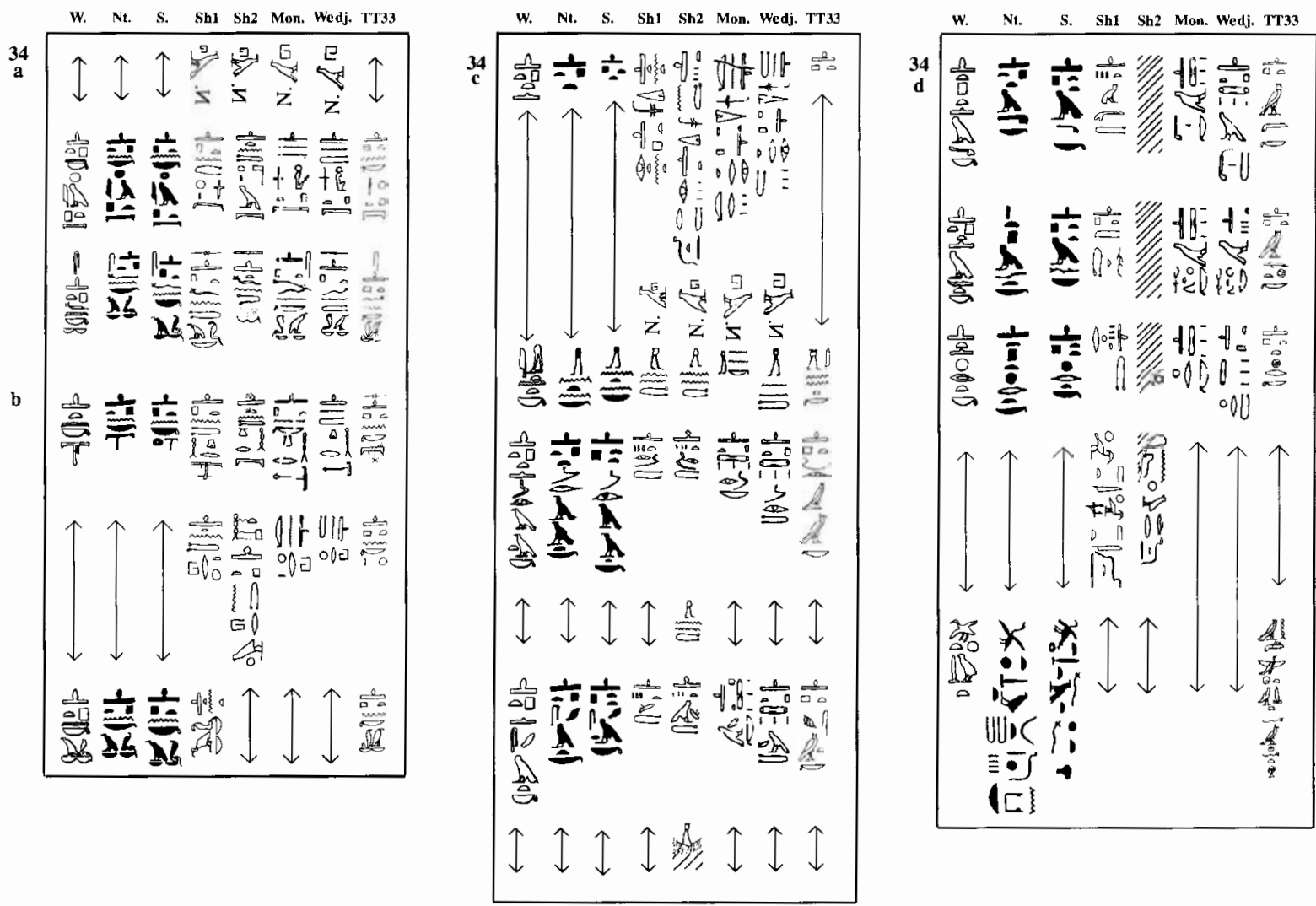

Fig. 5. Synoptic presentation of Pyramid Texts utterance 44

exemplars of PT $44,{ }^{33}$ from left to right Wenis $\left(\mathrm{W} .{ }^{34}\right)$, Neit $\left(\mathrm{Nt} .{ }^{35}\right)$, Senwosretankh $\left(\mathrm{S} .{ }^{36}\right)$, the already known table (Sh1), the newly recovered table (Sh2), the contemporary tables of Montuemhat (Mon. ${ }^{37}$ ), his wife (Wedj. ${ }^{38}$ ), and a famous Dynasty 26 exemplar (TT $33^{39}$ ). Finally, Shepenwepet on

33. Along with those shown in fig. 5, just enough of the text appears in the following sources to know that it was once fully borne by them as well: Pepi I (P.), see Isabelle Pierre-Croisiau, Les lextes de la pyramide de Pépy I ${ }^{e r}, 2$. Fac-similes, MIFAO 118/2 (Cairo, 2001), pl. 4 B (P/F/Ne I 81-84); Pepi II (N.), see Gustave Jéquier, Le monument funéraire de Pepi II, Tome 1 (Cairo, 1936), pl. 3 cols. 267-69; Wedjebteni (Oudj.), see Gustave Jéquier, La pyramide d'Oudjebten (Cairo, 1928), pl. 6, col. 34; Ibi (Aba), see Gustave Jéquier, La pyramide d'Aba (Gairo, 1935), pI. 5, col. 97; and Henenit (designated M1Ba by Günther Lapp, Typologie der Särge und Sargkammern von der 6. bis 13. Dynastie, SAGA 7 (Heidelberg, 1993), 288), see Günther Lapp. Särge des Mittleren Reiches aus der ehemaligen Sammlung Khashaba, ÄA 43 (Wiesbaden, 1985), pl. 35 middle. According to Catherine Berger-el Naggar et al., Les textes de la pyramide de Pépy $f^{e r}$, 1. Description et analyse, MIFAO 118/1 (Cairo, 200I). 70, Teti (T.) and Nemtiemzaf Merenre (M.) also bear this text, though the relevant elements are yet unpublished. Add to all of these a now lost or otherwise unknown offering table given vague reference by Daressy, "Notes et remarques," $75 \mathrm{n}$. 2, who reports that "Un fragment de table d'offrande donne le commencement du même texte," the relevant portion being: $h t p\langle n\rangle=k r^{\prime} i m y \mid p . t$ shtp=f $n=k n b . t i h t p$ । /l. Finally, compare also CiT VII 139c-d.

34 Tracing from the photograph of Alexandre Piankoff, The Pyramid of Unas (Princeton, 1968), pl. 61.

35 After Gustave Jéquier, Les Pyramides des reines Neit et Apouit (Cairo, 1933), pl. 11.

36 After William C. Hayes, The Texts in the Mastabeh of Se'n-Wosret-'Ankh at Lisht (New York, 1937), pl. 3, cols. 75-80.

37 After Barguet et al., "Les tables d'offrandes," pl. 1.

38 After Barguet et al., "Les tables d'offrandes," pl. 2.

39 After Johannes Dümichen, Der Grabpalast des Patuamenap in der thebanischen Nekropolis (Leipzig, 1884), vol. 1, pl. 7, cols. 27-28. 
the old table is designated as $m 3^{\prime}(. t)$-hrw but not on the newly discovered one. The presence and absence of the epithet used to be regarded as a sound criterion for establishing dates in this period, ${ }^{40}$ but Leclant has since noted that it "ne s'applique pas nécessairement à un défunt; son emploi pour un vivant ne se borne pas au Nouvel Empire," ${ }^{11}$ and with that realization it becomes difficult to argue for a relative date based upon this difference.

Though the temporal relationship between them may remain obscure, the incorporation of this Pyramid Text into the decoration of these tables is clearly important for several reasons. After the occurrence of a Pyramid Text utterance on the cylindrical support for a libation altar from the pyramid temple of Pepi $I^{42}$ the earliest preserved example of one on an offering table is from the New Kingdom offering table of Sarenenutit. ${ }^{43}$ It, however, does not include $P^{\prime} T$ 44. (In fact, these tables of Shepenwepet, together with the tables of Montuemhat and his wife Wedjarenes, bear the earliest exemplars of this particular text since the Middle Kingdom. ${ }^{44}$ ) After Dynasty 25, other offering tables with Pyramid Texts are attested, for example the Dynasty 26 table of an Amenirdisu (CG 23099), which bears both PT 25 and 32. ${ }^{45}$ Appearing also on the table of Sarenenutit ${ }^{46}$ and the Pepi I altar stand, ${ }^{47}$ the latter text is more characteristic of offering table inscriptions; it is a libation formula, thus the recitation made during the rite of pouring water onto the table itself: ${ }^{48}$ "This libation of yours, O Osiris, this libation of yours, $\mathrm{O}$ Amenirdisu, which went forth from ${ }^{49}$ your son, which went forth from Horus!" 50 This statement has a long history after Dynasty 26, taking on a life of its own as

${ }^{40}$ E.g., by Jean Leclant, "Le prêtre Pekiry et son fils le grand majordome Akhamenrou," JNES 13 (1954), 154-69, 168; Jean Leclant, Montuemhat quatrième prophète d'Amon, BdE 35 (Cairo, 1961), 266; and Leclant, Recherches sur les monuments, 357. And this criterion does not yet seem to have been universally abandoned, as when it is used by Luisa Bongrani Fanfoni, "Un nuovo documento di Scepenupet Ia e Amenardis Ia" in OrAnt 26 (1987), 65-71, 67-68.

41 Jean Leclant, "Varia Aethiopica," MDAIK 37 (1981), 289-97, 295 n. 43. A sharp illustration of the dubious value of $m 3^{\prime}$. hrw as a dating criterion is drawn out from the adoption stele of Ankhnesneferibre by Anthony Leahy, "The Adoption of Ankhnesneferibre," JEA 82 (1996), 145-65, 152 n. (v) and 160. Aidan Dodson, "The Problem of Amenirdis II and the Heirs to the Office of God's Wife of Amun during the Twenty-Sixth Dynasty," JEA 88 (2002), 179-86, 185, does not treat the term as a certain criterion.

42 With PT 32; see Jean Leclant, "Fouilles et travaux en Égypte et au Soudan, 1982-1983," Or 53 (1984), 350-416, 367 n. 92, and Jean Leclant, "Un support d'autel à libations du temple haut de Pépi Ier," in Sarah Israelit-Croll, ed., Studies in Egyptology Presented to Miriam Lichtheim, vol. 2 (Jerusalem, 1990), 653-55 and 1118-19.

4.3 See Clère, "La table d'offrandes," 213-234.

${ }^{44}$ See the enumeration of exemplars of PT 44 above at n. 33.

${ }^{45}$ See Kamal, Tables d'offrandes, 85 with pl. 21.

${ }^{46}$ For it, see Clère, "La table d'offrandes," 219 (Inscr. IIa).

${ }^{47}$ For it, see Leclant, “Un support d'autel à libations," 1118-19.

${ }^{48}$ According to Brigitte Altenmüller-Kesting, Reinigungsriten im ägyptischen Kult (Diss. Hamburg, 1968), 3 and 35-39, the rite, which involves the manipulation of qbh ntri $t 32$ "libation and 2 natron pellets" (see Pyr. 23b (W.)), is one of three rites leading up to the purification that prepares for the offering meal, but PT 32 "sich bei der Zeremonie um eine reine Libation handelt, nicht um eine Reinigungszeremonie"; rather, it is a matter of cooling the heart ( $q b b$ i $b$ ) of the beneficiary (see Pyr. 22b).

${ }^{49}$ The rendering of Raymond O. Faulkner, The Ancient Egyptian Pyramid Texts (Oxford, 1969), 6, as "gone forth to" is incorrect. As already seen by Fr. W. von Bissing, "Zur Geschichte der Libationsformeln," RT 23 (1901), 38-47, 39 (similarly Altenmüller-Kesting, Reinigungsriten, 35, with "durch"), the libation is come forth $h r$ from rather than to Horus. Compare Pyr. $905 a-c(N)$, where the sense of $h r$ in association with pri "to go forth" is clear: $h t p-d i-n i-s w . t n=k t=k h n q . t=k \mid p 3 d .(w) y=k(\hat{\imath}) p r . w$ $h r$ hr imi wsh.t $\mid$ shtp=fib=k im Ne. nd.t d.t "The offering given of the king to you: your bread, your beer, and your two pellets, which went forth from Horus, He in the Broad Hall, that he may satisfy your heart thereby, O Neferkare, for ever and ever." Horus, the ritualist, satisfies the objec of rite through the pellets' going forth $h r$ from himself to the latter; the ritualist does not satisfy the beneficiary through the ritualist's receiving the pellets. The Coffin Texts version of this statement, which adds a dative from $n$, verifies the directional value of $b r$ in this context, CT I 275b-f: $q b h=k i p n i t(=i) \mid q b h=k i p n$ wsir $|i w n=k h r z 3=k|$ $i w n=k h r h r$ "This your libation, O my father, this your libation, O Osiris, which came to you from your son, which came to you from Horus!" hr's use in indicating origin is observed by Elmar Edel, Altägyptische Grammatik, vol. 2, AnOr 39 (Rome, 1964), $\S 768 \mathrm{~d}$.

${ }^{50}$ Kamal, Tables d'offrandes, 85 with pl. 21: $q b h=k$ ipn wsir $q b h=k$ ipn imn-ir-dí-s(w) pr.zu hr $z 3=k$ pr.w hr hr. 
a formula subject to wide variation from its Old Kingdom ancestor, a phenomenon studied by von Bissing a century ago. ${ }^{51}$ The following example, on CG 23155, comes from the Ptolemaic Period, when it was quite popular: "Let me give you this libation, which went forth from your son, which went forth from Horus!" ${ }^{2}$ Within the broader historical context, the new table of Shepenwepet is a part of a long tradition of including Pyramid Texts utterances on offering tables.

That they do so is in full accord with the original position in life of many Pyramid Texts utterances; they are generally closely connected with mortuary service. ${ }^{53}$ Indeed, all of the texts just now mentioned-PT 25, 32, and our PT 44-are recitations from the offering ritual, ${ }^{54}$ the central element of the mortuary service. That fact situates Shepenwepet's tables squarely within mortuary service, though presumably the table's employment of the text from just one rite ${ }^{55}$ of the whole ritual is synecdochic, the part standing for the whole, the table used in more than just one rite.

More importantly, PT 44, as an ancient cultic recitation from a ritual already a millennium and a half old, stands on these offering tables as an appropriation of tradition, not only by the Nubians Shepenwepet and her contemporary Wedjarenes, but also by Montuemhat, who claims ancestry of multiple generations of Theban and Egyptian priests and functionaries. ${ }^{56}$ It is an appropriation of cultural identity already evident with the Pyramid Texts covering the interior walls of the chapel of Shepenwepet's predecessor, Amenirdis. ${ }^{57}$ It is an appropriation evident in the scenes decorating the innermost room of Amenirdis's chapel, scenes of mortuary service, ${ }^{58}$ which, but for the style of their rendering, could have been taken from an Old Kingdom mortuary chapel. ${ }^{59}$ Precisely the same scenes of mortuary service are employed by Shepenwepet II in her own chapel. ${ }^{60}$ In adopting these

51 See von Bissing, "Zur Geschichte der Libationsformeln," esp. 38-43. See further the supplementary material and observations at Fr. W. von Bissing, "Eine Libationsformel aus dem Neuen Reich," RT 25 (1903), 119-20, and Fr. W. von Bissing, "Zur Geschichte der Libationsformel, III," RT 30 (1908), 180-83.

52 Kamal, Tables d'offrandes, 115 with pl. 39: di( $=i) n=k$ qbh ipn pr.w hr $z$ 3 $=k$ pr.w hr $h r$.

53 As they are nowadays being understood once more; see Jan Assmann, Images et rites de la mort dans l'Égypte ancienne (Paris, 2000), 33 with n. 1 .

${ }^{54}$ Because of their relationship with elements of offering lists. On this relationship, see Hermann Junker, Giza $I J$ (Vienna, 1934), 80, and Harold M. Hays, "The Worshipper and the Worshipped in the Pyramid Texts," SAK 30 (2002), 153-67, 153-54. PT 25 corresponds to the second element of a more or less fixed offering list (number 2 of the table beginning at Junker, Giza $I I, 85$ ), which is already attested at the start of Dynasty 5, a list designated "Typ A" by Winfried Barta, Die altägyptische Opferliste, MÄS 3 (Munich, 1963), 72-76. PT 32 and 44 correspond to elements of a more or less fixed series of items that is designated as list “Typ B” by Barta; see Barta, Die altägyptische Opferliste, 78-79. This Type B list does not appear independently of the Type A list, but is always found within it. It is first recognizable within the offering ritual of Wenis, but it begins to appear in purely list form as early as the Middle Kingdom tomb of Amenemhat, for which see Percy Newberry, Beni Hasan Part I, ASE 1 (London, 1893), pl. 17. PT 32 and 44 respectively correspond to gbh ntri $t 32$ (the third item in the list of Amenemhat, which begins in the upper left corner) and $p 3 . t w d 3 . t$ (the eighteenth item in his list).

55 PT 44 deals with the presentation of a pi.t wds.t "a whole pat-cake" (Pyr. 34d). Concerning this item's significance, the $p 3 . t$ is repeatedly associated with the Eye of Horus in the PT, as at Pyr. 117a: $i r(. t) \grave{l} r p 3 . t n(i t) n t r . w$ ws $b(. t)=s n$ im "the Eye of Horus, the pat-cake of the gods, wherefrom they are nourished"; Pyr. 35b-c: $i n(. t) h r \mid p 3, t=k$ "the Eye of Horus, your pat-cake"; and Pyr. 78a: $i r . t h r p 3, t=k$ "the Eye of Horus, your pat-cake." As the $p 3 . t$ is explicitly emblematic of the Eye of Horus, the significance of the adjective $w d 3$ in $p 3 . t w d 3 . t$ is necessarily tied to the $i r . t$ hr wd $3 . t$ "the whole Eye of Horus," an image also repeatedly encountered in the PT, as at Pyr. 21 a, 54c, 55a, and 900a, with clear connotations to it at Pyr. 55c, 451b-c, and 2050a. The notion of wholeness or wellness becomes so intertwined with the Eye that, after the Old Kingdom, the word wd3,t alone comes to stand for the Whole Eye, especially (though not exclusively) the Whole Eye of Horus, as at CT IV 238/9b, IV 240/1b, IV 250/1a, VIl $373 \mathrm{a}$, VII $378 \mathrm{c}$, and VII $454 \mathrm{e}$.

56 Leclant, Montuemhat, $260-61$.

${ }^{57}$ For the texts, see G. Daressy, "Inscriptions de la chapelle d'Ameniritis à Médinet-Habou," RT 23 (1901), 4-18.

58 Nelson designation MH C 141 and 145, as yet unpublished; see OI Negatives 8353 and 8354.

59 Cf. e.g., Margaret Murray, Saqqara Mastabas Part I, ERA 10 (London, 1905), pl. 23. Such scenes of mortuary service are attested also in the Middle Kingdom, e.g., at Aylward M. Blackman, The Rock Tombs of Meir, Part II, ASE 23 (London, 1915), pls. 6-8, and in the New Kingdom, e.g., at Medinet Habu in the Small Temple, at Nelson designation MH B 75 and 78 , publication currently in preparation by the Epigraphic Survey.

${ }^{60}$ Nelson designation MH C 211 and 215, as yet unpublished; see OI Negatives 7924 and 7923 . 
tokens richly charged with evocation of the past, Shepenwepet, Amenirdis, Wedjarenes, and Montuemhat were all making themselves a part of that tradition.

It is within this context of tradition that the newly recovered table sits. And it was a tradition whose continuity was not factitious. ${ }^{61}$ Undoubtedly, the following Dynasty 26 is an "age of archaism par excellence," and certainly evidence of this trend may be detected already in Dynasty $25,{ }^{62}$ and even before then, with Kitchen, in the nature of the formal names of Osorkon III and Shoshenq V, about a century before the Saites. ${ }^{63}$ But as for the use of Pyramid Texts in the Late Period, Assmann rightly argues that it represents less a case of a revival of a dead textual tradition and more a case of certain texts in continual use from the Old Kingdom through the Ptolemaic Period. ${ }^{64}$

In fact, Pyramid Texts are attested in all periods from the Old Kingdom on, though of course more frequently in some periods than in others. ${ }^{65}$ For example, there are about forty-six individual Pyramid Texts attested in part or whole from the New Kingdom, ${ }^{66}$ compared to about four hundred from the Late Period. ${ }^{67}$ While the strikingly greater frequency of attestation in the Late Period should be interpreted as the result of an archaizing motive, leading to a greater interest in displaying them in durable media, it would be incorrect to say that the corpus of literature and the rites represented in

${ }^{61}$ A largely factitious continuity being one of the characteristics of a non-genuine or "invented" tradition; see Eric Hobsbawm, "Introduction: Inventing Traditions," in Eric Hobsbawm and Terence Ranger, eds., The Invention of Tradition (Cambridge, 1984), 3 .

62 A "return to the forms and lessons of the past" perceivable in it by Jean-Claude Goyon, "An Interpretation of the Edifice," in Richard A. Parker et al., The Edifice of Taharqa by the Sacred Lake of Karnak (Providence, 1979), 80 with reference at n. 9.

63 Kitchen, The Third Intermediate Period, 349-50 (\$309), from whom the quotation is taken.

${ }^{64}$ See Jan Assmann, "Egyptian Mortuary Liturgies," in Israelit-Groll, ed., Studies in Egyptology, vol. 1, 1-45, 24, who is speaking of the continuous use of liturgical manuscripts for the mortuary service. A position parallel to Assmann's is David P. Silverman, "Coffin Text Spell 902 and Its Later Usages in the New Kingdom," in L'égyptologie en 1979: axes prioritaires de recherches, (Paris, 1982), vol. 1, 67-70,69 with n. 16, where it is suggested that the attestation of CT 902 in the New Kingdom "indicates that the Egyptians had knowledge of and access to their own religious literature reaching back many centuries." Assmann and Silverman are exceptions, as there seems to be a tendency to characterize the attestation of PT in the Late Period as part of a broader, archaizing pattern, encountered at, e.g., Klaus Koch, Geschichte der ägyptischen Religion (Stuttgart, 1993), 452. It is a conception of venerable pedigree, going back at least as far as Georg Möller, Ueber in einem späthieratischen Papyrus des Berliner Museums erhalten Pyramidentexte (Berlin, 1900), 6, with an extreme variation of this notion at James H. Breasted, Development of Religion and Thought in Ancient Egypt (New York, 1912), 294 with n. 1, who says, "While a few scanty fragments of the Pyramid Texts have survived in the Book of the Dead, it may nevertheless be said that they have almost disappeared," adding, "Later, especially in the Saitic Age, they were revived"--an unfortunate statement that continues to appear in expanded paraphrase, as at T. G. H. James, A Short History of Ancient Egypt from Predynastic to Roman Times (Cairo, 1995), 138: in Dynasty 26, "Temple and tomb reliefs of earlier times were copied, as were the religious texts found in the ancient tombs, including close adaptations of the Pyramid Texts, otherwise found only in the royal sepulchres of the Old Kingdom."

65 As observed already by Möller, Pyramidentexte, $5-6$.

${ }^{66}$ Without considering resonant statements in the Opening of the Mouth and in temple ritual texts: and excepting short statements made on royal sarcophagi of Dynasty 18, the following is a representative list, for references to which see Thomas G. Allen, Occurrences of Pyramid Texts with Cross Indexes of These and Oiher Egyptian Mortuary Texts, SAOC 27 (Chicago, 1950), $61-$ 102, except where noted: PT 23 (TT 95, noted at Andrea Maria Gnirs, "Das Pfeilerdekorationsprogramm im Grab des Meri, Theben Nr. 95" in Jan Assmann et al., eds., Thebanische Beamiennekropolen, SAGA 12 (Heidelberg, 1995), 233-53, 241), PT 25 (e.g., TT 100), PT 32 (e.g., TT 93, see Norman de Garis Davies, The Tomb of Kenamun at Thebes (New York, 1930), pl. 56A), PT 94 (TT 353 a.k.a. Tm), PT 95 (TT 353), PT 108 (e.g., TT 107, for which see H. W. Helck, "Inhaber und Bauleiter des thebanischen Grabs 107," MIO 4 (1956), 11-26, 14), PT 113 (TT 107), PT 204-5 (e.g., TT 39), PT 207 (e.g., TT 39), PT 209-12 (e.g., TT 39), PT 219 (TT 353), PT 220-22 (e.g., TT 82), PT 223 (e.g., TT 100), PT 249 (TT 1 12, see Nina de Garis Davies, The Tombs of Menkheperrasonb, Amenmose, and Another (Nos. 86, 112, 42, 226), TTS 5 (London, 1933), pls. 26-27), PT 251-53 (TT 87), PT 268-69 (table of Sarenenutit), PT 275-76 (Sarenenutit), PT 307 (Sarenenutit), PT $311-12$ (TT 57), PT 356-57 (TT 82), PT 364 (TT 82), PT 366-67 (TT 353), PT 368 (e.g., TT 87), PT 422 (TT 39), PT 424 (TT 353), PT 431-32 (TT 353), PT 450-51 (TT 11 ), PT 540 (MH B 166-69, for which see Kurt Sethe, “Das alte Ritual zur Stiftung von Königstatuen bei der Einweihung eines Tempels," ZÄS 70 (1934), 51-56, 52-55), PT 644 (TT 100), PT 650 (MH B 166-69), and PT 677 (TT 82).

${ }^{67}$ Massimo Patanè, "Au sujet des Textes des Pyramides les plus fréquents à la Basse Époque," BSEG 16 (1992), 65-67, 65, finds in his corpus of PT “à la Basse Époque environ quatre cents formules répétées en tout près de mille fois." Besides the sources listed in Allen, Occurrences, see Massimo Patanè, Les variantes des Textes des Pyramides à la Basse Époque (Geneva, 1992), ii-v. 
it had previously fallen out of use. Besides the simple fact that Pyramid Texts are attested in the New Kingdom, it may be observed that fully one quarter of those attested in the Late Period-109 of them ${ }^{68}$-are the recitations for the rites specified in a type of offering list ${ }^{69}$ repeatedly attested in the New Kingdom. ${ }^{70}$ This correspondence provides ground for one to believe that these 109 Pyramid Texts were indeed known in the New Kingdom, and to go on to conclude that it is only an accident of preservation that no full copies of them survive from that period. PT 44, on our newly recovered table, is one of these 109 texts. ${ }^{71}$ In light of these things, it would be difficult to see its attestation in Dynasty 25 as evidence of a revival of a dead textual tradition. Rather, it is easier to say that it constitutes the surviving written expression of something in the continuous possession of the society that authored it. Its use by Shepenwepet was an appropriation of tradition, but it was through the appropriation that the tradition was kept alive.

Transliteration and Translation of the New Table (right to left): ${ }^{72}$

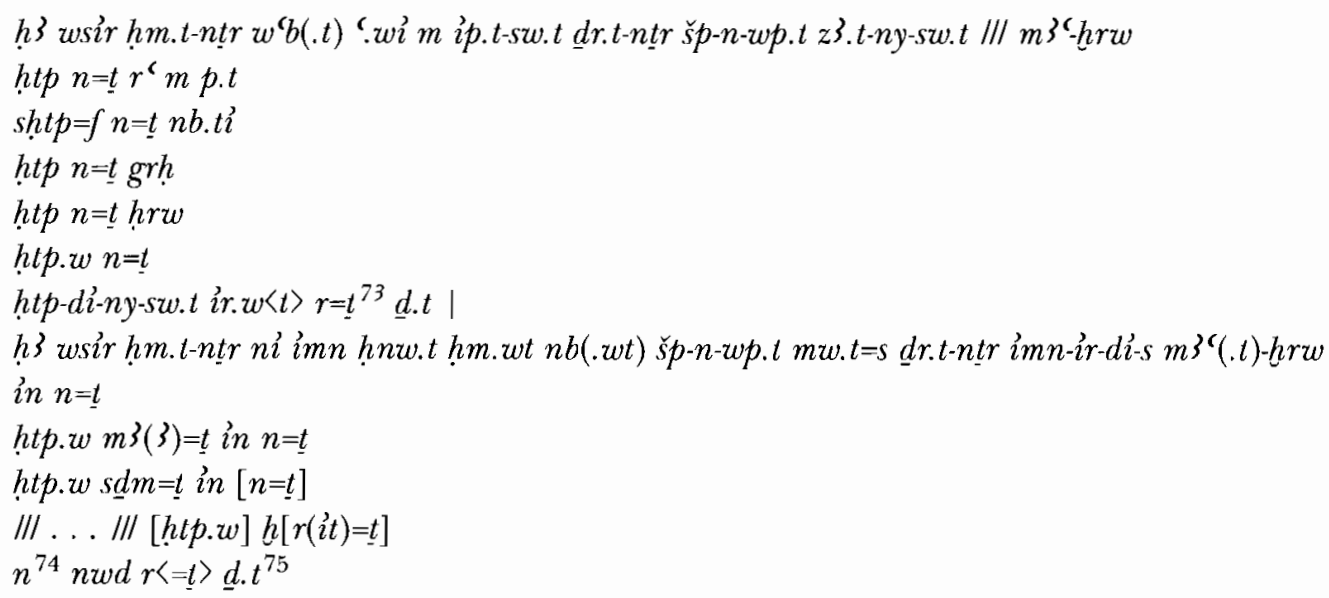

O Osiris the God's Wife Pure of Hands in Karnak, God's Hand Shepenwepet, King's Daughter of /II True of Voice,

Re who is in the $\mathrm{sky}^{76}$ is satisfied with ${ }^{77}$ you,

${ }^{68}$ For the following references, see Allen, Occurrences, 61-102: from TT 33, PT 23, 25, 32, 43-57, 72-79, 81-96, 108-71; from Tchannehibu, PT 34; from Psamtik, PT 35; from Pediniese, PT 107.

69 See above n. 54.

70 The "Typ A bzw. A/B" list, shown as appearing in seven sources in Barta, Opferliste, 162-63.

71 The list correlate of PT 44 appears al, e.g., Davies and Gardiner, Tomb of Amenemhet, pl. 18 ( $p 3 . t$, in the tenth box from the right).

72 For a translation of the previously known table, Sh1, see Barguet et al., "Les tables d'offrandes," 507.

73 Compare Shl ir.t $n=t$; Mon. ir.wt $r=k$; and $W e d j$. ir.wt $\langle n\rangle=t$. Observe that in all but one case, iri receives plural strokes, and that in all but one case, it is inflected as a feminine, and is consequently not in gender-number accord with htp-di-ny-szu.t. The interpretation of $r$ on two of the offering tables, though ordinarily adversative with iri (and therefore worthy of note by Barguet et al., "Les tables d'offrandes," $493 \mathrm{n}$. 1) is clarified by Sh l's $n$.

74 The orthography is unusual, but the reading is certain; see the following note.

${ }^{75}$ See two other, contemporary tables from TT 34 also bearing this clause, at Barguet et al., "Les tables d'offrandes," 497 n. 8 and pls. 4 and 5 .

${ }^{76}$ As a substantive name of $\mathrm{Re}$, the phrase $i m(i)$ p.t occurs also at Pyr. $37 \mathrm{~b}$, as seen by the translation of James P. Allen, The Inflection of the Verb in the Pyramid Texts (Malibu, 1984), $\$ 54$ A.1. As an epithet of $r^{\prime}$, it continues to appear in later religious texts, e.g., CT I 54j and I 55d; cf. VI 177h. nti introduces the same attributive in association with Thoth and the Elder Horus in the Coffin Texts, at CT VII 380a: ih $\underline{\text { dhw ti } n w} n t(i) m$ p.t "This is the Moon, Thoth who is in the sky" and CT VII $445 \mathrm{~b}$ : hr smsw $n w n t(i) m$ p.t tw nb.t p.t "This is Horus the Elder who is in all of this sky of the sky." 


\author{
him making the Two Ladies satisfied ${ }^{78}$ with you; \\ and the night is satisfied with you, \\ and the day ${ }^{79}$ is satisfied with you! \\ The offering ${ }^{80}$ be yours: \\ the ${ }^{81}$ offering given of ${ }^{82}$ the king is what is ever performed toward ${ }^{83}$ you- \\ O Osiris the God's Wife of Amun, Mistress of All the Women, her mother the God's Hand Amen- \\ irdis True of Voice- \\ and is what is brought to you; 84
}

77 htp $n$ "be satisfied with, because of" frequently appears in the PT, as at Pyr. 1b, 103c, 611a, 639a, 708b, 1088b, and 1088c, and in later mortuary texts, as at CT I $57 \mathrm{~b}, \mathrm{I} 77 \mathrm{a}$, and I 77b, and appears with this meaning even later, in the Ptolemaic Period (see Wb iii 189.1: "zufrieden sein mit etw."). htp and shtp in the context of ritual can refer to the state brought about through ritual's performance. See e.g., Pyr. 59c: $m-n=k$ ir.t $h r$ htp $h r=s$ htp wsh.t 2 "Take the eye of Horus! Be satisfied with it! Two broadhall offerings"; Pyr. 897b: shtp tw hr $m$ htp $h r(i)=f$ "Let Horus satisfy you with the offering that is with him"; and Pyr. $1116 d$ : $s h t p=f$ is $m p\}_{q=s}$ "that he satisfies (the Ennead) with its paq-cake." For a personage being shtp through the agency of Re, cf. CT I 300a: $s h t p=k m$ ' $r$ " May you be made satisfied by the hand of Re."

${ }^{78}$ Besides the discussion in the following note, cf. the personage called $h t p=s-h w=s$ "As she is satisfied, so does she protect" at CT IV 256/7a and IV 260/1b, where, in Sq4Sq and M57C respectively, the name is determined with a cobra-sign.

${ }^{79}$ With the reference to $n b . t 2$ in the preceding statement and the pairing of $g r h$ and $h r w$, one may see an allusion to the beneficiary's being conceived and born. For the constellation of day and night, birth and conception, and the two diadems, see Pyr. 714a-b (T.): msiz.wt grh mil ms T. I iwr.ty hrw $3 w$ tn(i) $m s=t n(i)$ sw imi swh.t "A birth at night! Come! Teti is born! O two who conceive by day, present yourselves (lit. be long) and bear him, the one who is in his egg!" (Cf. exemplar P. at Pierre-Croisiau, Les textes de la pyramide de Pépy $I^{e r}, 2$., pl. 9 (P/A/E) 4, which replaces msỉ.wt grh "a birth at night" with ms.tígrh "O two who give birth at night"). The iwr.ty who are to bear the beneficiary are understood by me as the two diadem goddesses, since especially Nekhebet elsewhere performs the role of conceiving and bearing; see Pyr. 568a (sim. 569a): i.iwr nr.t [m] $M$. $m$ šs.$t$ "The vulture (i.e., Nekhebet) is pregnant [with] Merire in the night sky"; and Pyr. $1370 \mathrm{a}$ : . . sm 3.t hm.t wr.t iwr-s sw msi=s sw" . . the Great Wild Cow, she conceiving, she bearing him" (for the identity of sm3.t hm.t wr.t as nhbw.t; see Pyr. 729a-b and 2003a, through the epithet hrit-ib nhb "She who is resident in Nekheb," and 1566a, through the epithet 3w.t š.ti "long of plumes"; the identity of the Great Wild Cow with Nekhebet is noted by Helmut Bonnet, Reallexikon der ägyptischen Religionsgeschichte (Berlin, 1952), 507). For both diadems giving birth, see Pyr. 1425c-1427a: 3h.ty nb.t(i) t3 pn . . iw $=s n(i) h m m s . n=s n(i) n=s n(i) m P$. “the two Akhet-diadems, the Two Ladies of this land.. . . They indeed gave birth to Pepi for themselves," as well as Pyr. 1719a-b (sim. 804a and 1017c): ms.n tw z3.ti bi.ti | tp.ti nbw wrrt "The two daughters of the king of Lower Egypt, who are upon the possessor of the wereret-crown (i.e., who are the diadems), bore you"; see also Pyr. 198b-c for the beneficiary's being born by ih.t-wur.t i.e., the uraeus (see Sally B. Johnson, The Cobra Goddess of Ancient Egypt (London, 1990), 10 n. 53, for the identity of $i h . t$ with $3 h . t$, which would make for a meaning "Great Akhet-Diadem"; in contrast, see Kurt Sethe, Übersetzung und Kommentar zu den altägyptischen Pyramidentexten (Gluckstadt, 1935), vol. 1, 113, where it is held that ih.t-wr.t is constructed from ih.t "thing," in turn a euphemism for "fire," making the term a reference to the "feuerspeiende Uräusschlange") and Adolf Erman, Hymnen an das Diadem der Pharaoner (1911), 10, 4, for $n b . t h^{\varsigma} m$ h $3 . t m s=s$ "the Mistress of the Crown being in the brow of the one whom she bore." The close association of conception and birth, day and night is attested outside of Pyr. 714a-b; see Pyr. 705c: $s d r$ T. iur ms $r^{\prime} n b$ "Let Teti pass the night, being conceived and born every day!"; see also Pyr. 132a and 698d. Ultimately day and night are figures for the solar cycle: birth and conception.

${ }^{80}$ The plural strokes added to $h t p$, to make $h t p . w$, here and in all subsequent instances of words built from the stem on Sh2 (so also consistently in Sh1, Mon., and Wedj., beginning with the next $h t p . w$ ) graphically contrast these forms from the preceding, verbal forms, thus indicating that they are regarded substantively, just as in W., Nt., S. the substantive $h t p . t$ is hereafter used.

${ }^{81}$ As observed by Helmut Satzinger, "Beobachtungen zur Opferformel: Theorie und Praxis," LingAeg 5 (1997), 177-188, 180-82, htp should be treated as definite rather than indefinite, since it is modified by a relative form (or, as interpreted here, a passive participle with genitival agent).

${ }^{82}$ Here interpreting the verb form di with Alan H. Gardiner, "The Mansion of Life and the Master of the King's Largess," JEA 24 (1938), 83-91, 89 n. 1, as a passive participle.

${ }^{83}$ Concerning the use of $r$, see above, n. 73 .

${ }^{84} \ln$ in.t $n=k$ of Nt. and S. (with $i n . t n\{t\}=k$ in $W$.), a substantive, "what is brought to you." For htp.w/htp.l "offerings" being brought, see Pyr. 133c: in.n=f $d f$ 3.w htp.w $n h r$ hnti pr.w "with him having brought provisions and offerings to Horus Foremost of the Houses" and CT II 137d: in $t(w) n=i h t p . w$ "Bring me offerings!" Cf. the beneficiary being brought to offerings at Pyr. 536b: in 3 '3 pw mr Ne. pn in.w Ne. $r$ htp.t "Ah, it is the ones who bring, who love Neferkare, who bring Neferkare to the offering!" 
the offering is what you see, ${ }^{85}$ and is what is brought to you;

the offering is what you hear, ${ }^{86}$ and is what is brought [to you];

III . . //I [the offering is what is with yo] ${ }^{87}$

without cease ${ }^{88}$ concerning 〈you〉, for ever!

\section{The Epigraphic Survey Luxor, Egypt}

${ }^{85}$ A substantive in W., Nt., and S., with $m 33 . t=k$ "what you see." The notion of seeing offerings occurs also at Pyr. 818a-b, though there with $p h r$ instead of $h t p: m\}=k p h r p n \mid$ ir. $n n=k n i$-sw. $\operatorname{ir} n n=k$. hnt $(i)$-imn.tiw "and see this reversion-offering, which the king made for you, which Khentimentiu made for you," For phr as "reversion-offering," see Goedicke, Königliche Dokumenle,

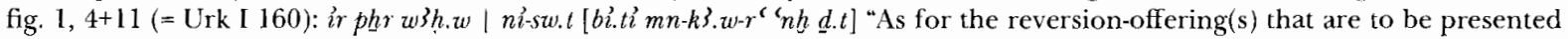
(to) the king of Upper [and Lower Egypt, Menkaure, living for ever,]" and of. phr.t and its food-stuffs determinatives at CI II 263b (B9G): ir=sn $n=i$ phr.l hnhnw "thal they may perform the reversion-offerings of the henhenu-bark for me"; $\mathrm{B} I \mathrm{P}$ replaces phr.t with $h 3 \mathrm{~m} l$ hnq.t "a thousand bread and beer."

${ }^{86}$ This statement reveals the aural dimension of ritual, since the offering is nol only seen but heard; it therefore includes the words recited during the presentation of a physical object, the thing that is seen. The combination of $m 3\}$ and $s d m$ constituting an act of witnessing occurs also at Pyr. 1007a-b (sim. 1976a-b): ' $\left.\left.h^{`} m\right\}=k n n ' h^{`} s d m=k n n \mid i r . n n=k z\right\}=k i r n n=k h r$ "Arise and see this; arise and hear this, which your son did for you, which Horus did for you!" See also Pyr. 53b and $979 \mathrm{a}$, though there it is the beneficiary who is being seen and heard.

${ }^{87} h r(i) t=k$, lit. "what is with/to you," is a substantive nisba in W., Nt., and S.

88 On $n$ nwd, see Kurt Sethe's interpretation of this phrase as reported at Battiscombe Gunn, "The Berlin Statue of Harwa and Some Notes on Other Harwa Statues," BIFAO 34 (1934) 135-42, 140: "ohne Aufhören." 